\title{
リン酸カルシウム系セラミックの歯周治療への応用
}

\section{Hydroxyapatite についての基礎実験}

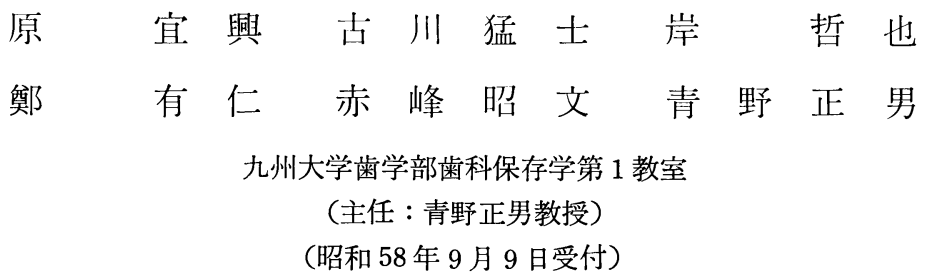

\section{Application of Calcium Phosphate Ceramics to Periodontal Therapy}

1. Fundamental Studies on Hydroxyapatite

\author{
Yoshitaka HARA, Takeshi FURUKAWA, Tetsuya KISHI, \\ Y.-J. CHENG, Akifumi AKAMINE and Masao AONO \\ Department of Periodontics and Endodontics, Faculty of Dentistry, Kyushu University
}

(Director : Prof. Masao AONO)

To decide the application of hydroxyapatite to periodontal therapy, following fundamental studies on hydroxyapatite were performed.

Materials used were six kinds of hydroxyapatites of which firing temperature were $900^{\circ} \mathrm{C}$ (LT) and $1,400^{\circ} \mathrm{C}(\mathrm{HT})$, and diameter were less than $100 \mu \mathrm{m}$ (size S), 200 300 $\mu \mathrm{m}$ (size $\mathrm{M}$ ) and $500 \sim 1,000 \mu \mathrm{m}$ (size L).

To investigate the surface ultrastructure of the hydroxyapatites with different firing temperature, LT-size $M$ and HT-size $M$ were coated with gold and observed scanning electron microscopically.

Dissolving each hydroxyapatite in pure water and $0.1 \%$ hydrochloric acid, specific electron conductivity test was carried out to compare the solubilities.

Each hydroxyapatite was implanted in $M$. rectus femoris of rats, and in artificial bone defect cavity (measuring $1 \times 3 \times 1 \mathrm{~mm}$ ) on maxillas and mandibles of dogs. These animals were sacrified two or four weeks after implantation. Then tissue response against hydroxyapatite and osteogenic activity of hydroxyapatite were examined histopathologically. The results obtained were as follows.

1) On scanning electron microscope, LT showed fine granular surface, but on the other hand, HT showed smooth surface.

2) Specific electron conductivity test presented higher solubilities in LT than HT.

3) At two and four weeks after implantation in muscles, all hydroxyapatites were enclosed with fibrous capsules involving foreign body giant cells and isolated from surrounding muscular tissues.

4) At two weeks after implantation in artificial bone defect cavity, foreign body response was not seen. Bone repairs in both case-LT and case-HT were more delayed than in control case, but that in case-LT was more prompt. Osteblastic cells coexisted with fibrobrasts in the connective tissue filling the artificial bone defect cavity and were in immediate contact with hydroxyapatite.

At four weeks after implantation, bone repairs had almost already completed in control and all hydroxy. apatite. 
At two and four weeks, there was no foreign body response and inflammatory cell infiltration. non-inflammatory and non-stimulative, and had good tissue tolerance and some kind of osteogenic activity.

Considering above results, hydroxyapatites were

Key words : Hydroxyapatite, Periodontal therapy, Tissue response, Osteogenic activity, Histopathological study

要旨 : 燒成温度 $\left(900^{\circ} \mathrm{C}\right.$ および $\left.1,400^{\circ} \mathrm{C}\right)$, 粒子の径 $(100 \mu \mathrm{m}$ 以下, $200 \sim 300 \mu \mathrm{m}$ および 500 1, 000 $\mu \mathrm{m})$ が異なる 6 種類の hydroxyapatite を歯周治療に忘用すべく, その基礎実験として表面微細構造の観察, 比電導度試験, 2 週と 4 週のラット笳肉内埋入試験およびイヌ顎骨内埋入試験を行い, 以下に示す結論を得た。

1. 焼成温度 $900^{\circ} \mathrm{C}$ の hydroxyapatite の表面微細構造は, 微細顆粒状を呈し, $1,400^{\circ} \mathrm{C}$ ののはより滑沢であっ た。

2. 比電導度試験では, 焼成温度 $900^{\circ} \mathrm{C}$ の hydroxyapatite の方がより高い溶解性を示した。

3. 筋肉内埋入試験では, 2 週および 4 週例共に, hydroxyapatite 周囲に異物巨細胞の出現を伴う被膜形成を認め, 軽度の慢性炎症性細胞浸潤があった。

4. 顎骨内埋入試験 2 週例では, 焼成温度 $900^{\circ} \mathrm{C}$ の hydroxyapatite の方が, やや速やかな骨修復像を呈していた が，対照群に比べると実験群はすべてやや遅れていた。また，骨欠損窝洞内の結合織中にも，骨芽細胞様細胞が hydroxyapatite をとり囲むように存在していた。

4 週例では，対照群およびほとんどの実験群で骨修復はほぼ完了していた。

2 週例および 4 週例共に，異物巨細胞の出現はごく稀であり，被膜形成や急性炎症の所見はみられなかった。 以上の結果より, hydroxyaaptite は非刺激性で, 生体親和性と骨誘導能を有することが推察された。

索引用語 : ハイドロキシアパタイト, 歯周治療, 組織反応, 骨誘導能, 病理組織学的研究

\section{緒言}

hydroxyapatite, tri-calcium phosphate (TCP), bioglass および almina ceramic などのセラミック類は, 生体との親和性が高く生体側の異物反応を引き起こさな い“医用材料 biomaterial”として, 整形外科や歯科領 域で注目を集めている。特に現在歯科領域では，それら のセラミック類を implant 材として適用した多くの報 告があり，既に臨床応用されているものもある。そのう ち hydroxyapatite に関する報告は implant 材として塊 状のものを実験材料としたものが多いようであるが，歯 周治療特に辺縁性歯周炎において歯槽骨の回復を図る場 合には，様々な骨欠損の形状に自在に適用しうる顆粒状 のものの方が, 塊状のものよりも有利と思われる。
我々はリン酸カルシウム系セラミックである顆粒状の hdroxyapatite の医用材料としての性質を知り, 臨床応 用の可否を検討するための基礎実験として, hydroxyapatite と組織反応および hydroxyapatite の骨誘導能 について検索した。

\section{材料・方法}

使用した材料は，京セラ社製 hydroxyapatite で，焼 成温度は $900^{\circ} \mathrm{C}(\mathrm{LT})$ および $1,400^{\circ} \mathrm{C}$ (HT) の 2 種, 粒 子の径は $100 \mu \mathrm{m}$ 以下 (size S), 200〜300 $\mu \mathrm{m}$ (size M) および 500 1, $000 \mu \mathrm{m}$ (size L) の 3 種, 計 6 種を 用いた (表 1 )。

動物実験に先立ち, hydroxyapatite の表面微細構造を 知るために, 焼成温度の異なる LT および HT-size M

表 1 実験に使用した hydroxyapatite

\begin{tabular}{|c|c|c|c|c|}
\hline & & $\sim 100 \mu \mathrm{m}$ & $\begin{array}{c}\text { 粒子の 径 } \\
200 \sim 300 \mu \mathrm{m}\end{array}$ & $500 \sim 1,000 \mu \mathrm{m}$ \\
\hline $\begin{array}{l}\text { 焼 } \\
\text { 成 } \\
\text { 温 } \\
\text { 度 }\end{array}$ & $\begin{array}{r}900^{\circ} \mathrm{C} \\
1,400^{\circ} \mathrm{C}\end{array}$ & $\begin{array}{l}\mathrm{LT}-\text { size } \mathrm{S} \\
\mathrm{HT}-\text { size } \mathrm{S}\end{array}$ & $\begin{array}{l}\mathrm{LT}-\text { size M } \\
\mathrm{HT}-\text { size M }\end{array}$ & $\begin{array}{l}\mathrm{LT} \text { - size } \mathrm{L} \\
\mathrm{HT}-\text { size } \mathrm{L}\end{array}$ \\
\hline
\end{tabular}




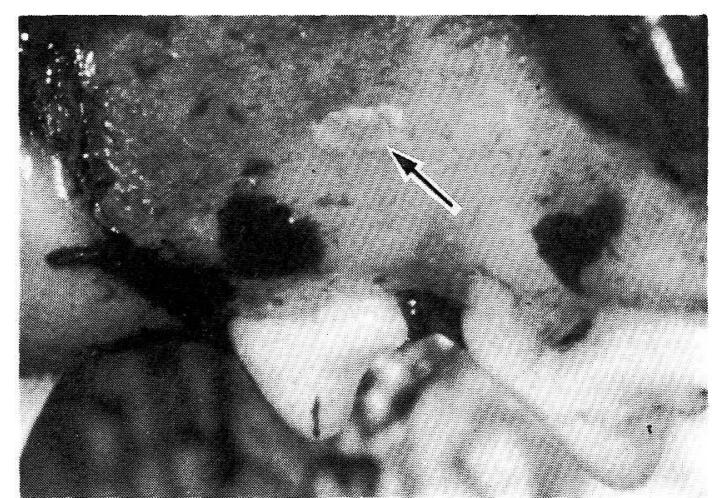

図 1 イヌ上顎骨欠損窩洞内人 hydroxyapatite を眞塞したところ

に金蒸着し，走査型電子顕微鏡（日立電子製 $\mathrm{H}-400$ ) を 用い，加速電圧 $200 \mathrm{kV}$ で観察した。

ついで hydroxyapatiteの溶解性をみるために，0.1\% の希塩酸および純水を溶媒とし, $250 \mathrm{mg}$ の各 hydroxyapatite を溶質とした場合の比電導度の相違を, 電気伝 導度計（東要電波工学 Model CM-6A）にて測定した。

実験は, hydroxyapatite に対する組織反応を観察する ためにラットの筋肉内埋入試験を，また hydroxyapatite の骨誘導能をみるためにイメの顎骨内埋入試験を行っ た。

筋肉内埋入試験は，エーテル麻酔下に 5 週 令の雌性 Wistar-King A 系ラットの左側大腿部を除毛し，皮膚お よび大腿直筋に縦切開を入れ，管肉内に各 hydroxyapatite を約 $25 \mathrm{mg}$ 埋入した。笳肉は非吸収性の縫合用 ナイロン糸で 2 カ所縫合, 皮膚は吸収性の縫合系で縫合 した後, 生体用アロンアルファで接着した。処置後 2 週 掠よび 4 週目に屠殺し，各 hydroxyapatite の埋人され た筋肉を摘出, $10 \%$ 中性フォルマリン固定後，エタノー ル系列で脱水し，パラフィン包埋した。これを約 $4 \mu \mathrm{m}$ に薄切し, H.E. Azan 染色を施して光顕標本とした。

顎骨内埋入試験は, 雌雄成犬を somnopentyl 静脈麻 酔，およびキシロカイン浸潤麻酔下に下顎左右小臼歯部 歯肉骨膜弁を剝離し， $\mathrm{P}_{1}, \mathrm{P}_{2}$ 閒㧍よび $\mathrm{P}_{2}, \mathrm{P}_{3}$ 間の賽側骨 面にタービンを用いて $1 \times 3 \times 1 \mathrm{~mm}$ の骨欠損窩洞を計 4 力所形成した。3 3 所の骨欠損窩洞にLT の 3 種の hydroxyapatite を, 生理食塩水を含んだ小綿球で圧迫 し填塞した（図 1)。残る 1 力所の骨欠損窩洞 は, 対照 として何も塻塞せずそのまま歯肉骨膜弁を絹系にて縫合 した。同様の処置を HTに関しても行い, 各 hydroxya-

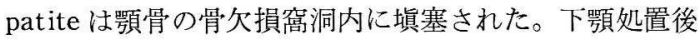

2 週目に上顎にも同様の処置を行い，更にその 2 週後に 屠殺して，下顎を 4 週例，上顎を 2 週例とした。摘出し た顎骨をノコで分割し，10\% 中性フォルマリン固定後， 橋本式交流電気脱灰器で脱灰, エタノール系列で脱水し, パラフィン包埋した。これを約 $4 \mu \mathrm{m}$ に薄切し, H.E. および Azan 染色を施して鏡検した。

\section{結 果}

\section{1. 表面微細構造}

弱払大では，LT および HT 共に，その表面は軽度の 起伏を呈しており，表面微細構造に特に顕著な差異は認 め難かった（図 2,3 )。強拡大では LT の表面には多く の微細な顆粒状の山凸がみられるのに対し，HT の表面 には散在する孔を認めるが，LT にみられる微細な顆粒 状の凹凸はみられず，より滑沢であった（図 4，5）。

\section{2. 比電導度試験}

比電導度試験では, 高い伝導度を示す強酸や強アルカ リなどの溶媒では，溶質が溶解することにより伝導度は 減少し，伝導度の低い純水では逆に伝導度は上昇する。

希塩酸を溶媒とした場合, LT の方が時間の経過 と共 により急な下降曲線を描き，高い溶解性を示していた (図 6 )。

純水を溶媒とした場合, LT の方が時閒の経過と共に 急な上昇曲線を描き，やはり高い溶解性を示していた (図 7 )。

\section{3. 筋肉内埋入試験}

2 週例においては，いずれの hydroxypaptite も線維 性被膜が被包することにより，周囲筋組織と隔てられて いた（図 8)。また,多核の巽物巨細胞が hydroxyapatite に密着する所見むみられた（図 9 )。結合織内一の炎症 性細胞浸潤は, リンパ球や形質細胞を認めるのみであ り，各 hydroxyapatite に対する組織反応に著明な差異 は認めなかった。

4 週例においては，2 週例とほぼ同様に hydroxyapatite は線維性被膜に被包されており, 結合織一の慢 性の炎症性細胞浸潤は軽度になっていた（図 10, 11)。 なお 2 週例および 4 週例を通じて, hydroxyapatite 周囲 の筋組織に変性，壊死などの細胞障害所見はみられなか った。

\section{4. 顎骨内埋入試験}

処置後 2 週例に扝いて，対照群では再生骨梁が既存の 骨組織から伸びるようにして，骨欠損部の修復が起こっ て㧍り，久損部表層でも久損部を閉鎖するような形で骨 


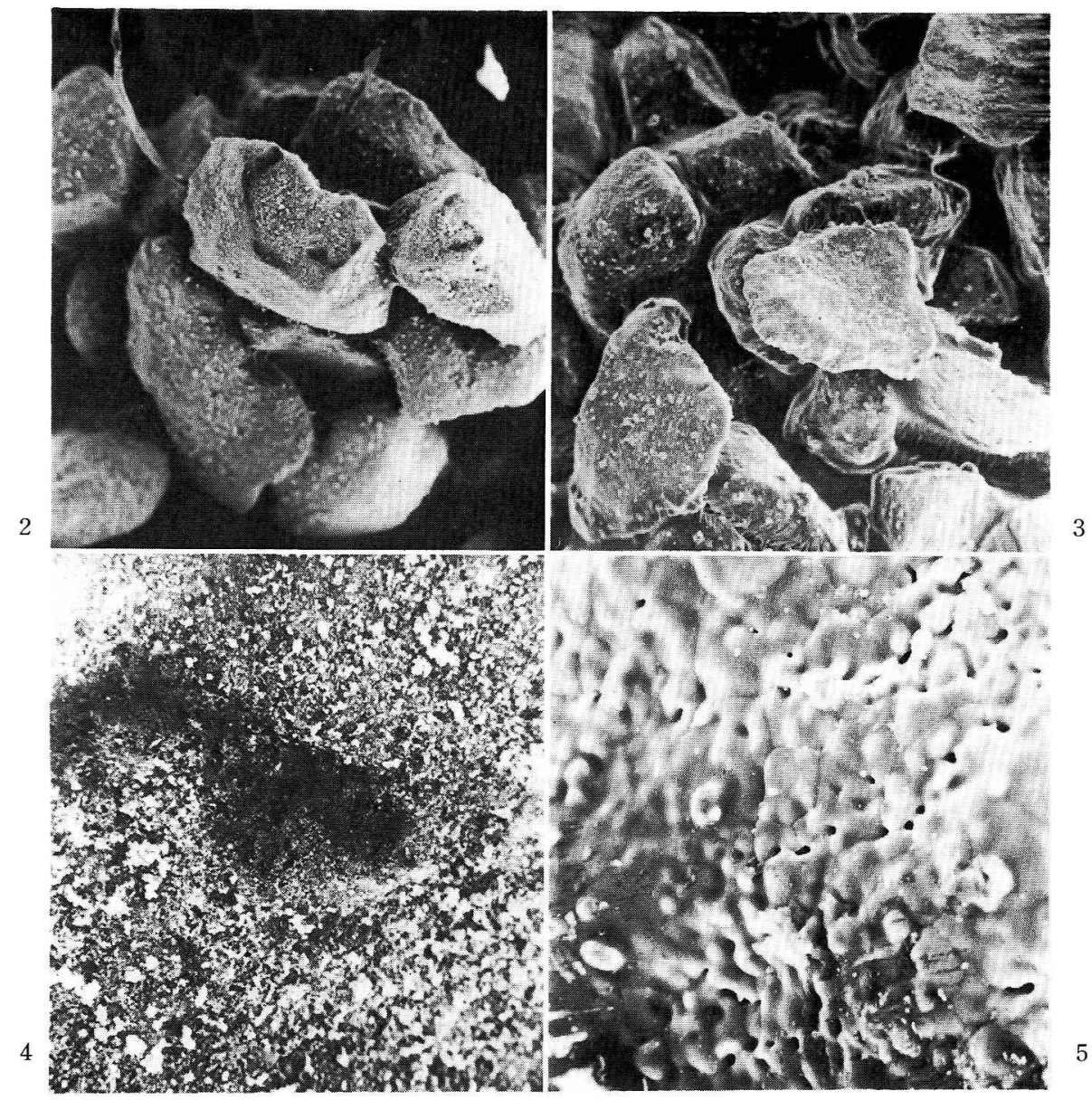

図 2 LT-size M の走査電顕像。 $\times 60$

図 3 HT-size M の走査電顕像。 $\times 60$

図 4 図 2 の強扡大像。表面は微細顆粒状を呈している。×700。

図 5 図 3 の強抎大像。散在する孔がみられ，表面はより滑沢である。 $\times 700$

梁が伸びていた（図 12）。この再生骨梁に接して，Azan 染色で細胞質が赤染する骨芽細胞がみられた（図 13 )。

LT-size S では，骨組織から伸びる骨梁が軽度にみら れ，骨組織から離れた結合織中にも類骨様構造物がみら れた（図 14, 15)。再生骨梁内には埋入された hydroxyapatite みみれ, Azan 染色では hydroxyapatite を埋 入した再生骨梁をとり囲んで，細胞質が赤染する骬芽細 胞を認めた（図 16）。また骨欠損部中央の，未だに再生 骨梁や類骨様構造物のみられない結合織内では, hydroxyapatite に密接して線維芽細胞が存在しており, これらの細胞の中には Azan 染色で赤染する骨芽細胞様 細胞もみられた（図 17)。

LT-size M および size L では, size S に比べ, hydro- xyapatite に密接した骨梁の再生をより多く認めた（図 18)。再生骨梁や, 結合織内の hydroxyapatite に接し て, Azan 染色で細胞質が赤染する骨芽細胞様細胞の存 在状況は LT-size S と同様であった。

HT-size S では骨梁の再生はほとんどみられず，骨組 織内面に新生骨の添加をわずかに認めるのみであった (図 19)。骨欠損部中央の結合織中では, hydroxyapatite に線維芽細胞が密接して存在していたが，Azan 染色で 赤染する骨芽細胞様細胞の数は, LT-size S に比べてか なり少なかった。

HT-size M および size L では, hydroxyapatite に接 して骨梁の再生を認めたが, LT-size M および size L にみられた骨梁再生と比べると，その程度はやや劣って 


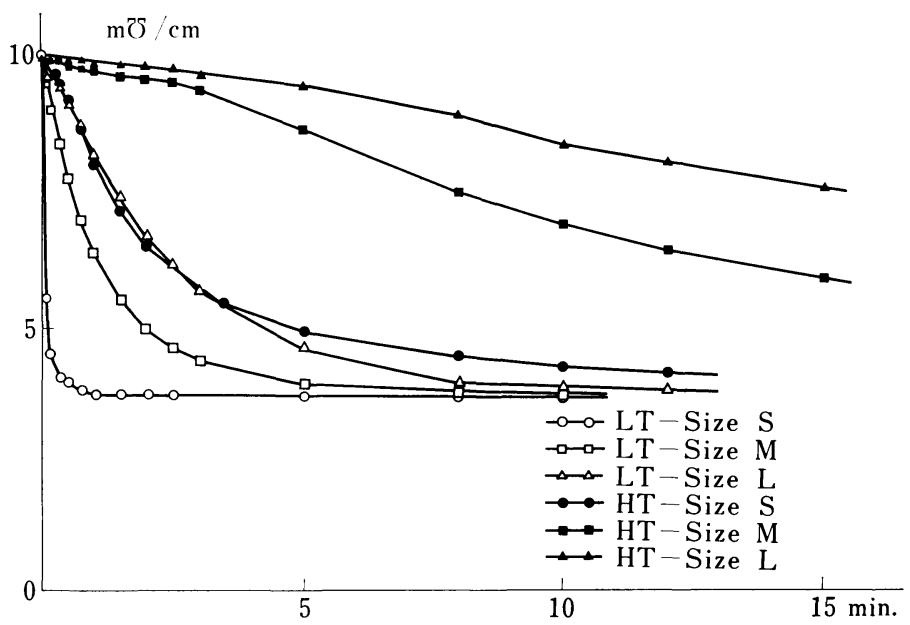

図 $60.1 \%$ 希塩酸を溶媒とした場合の比電導度の変化

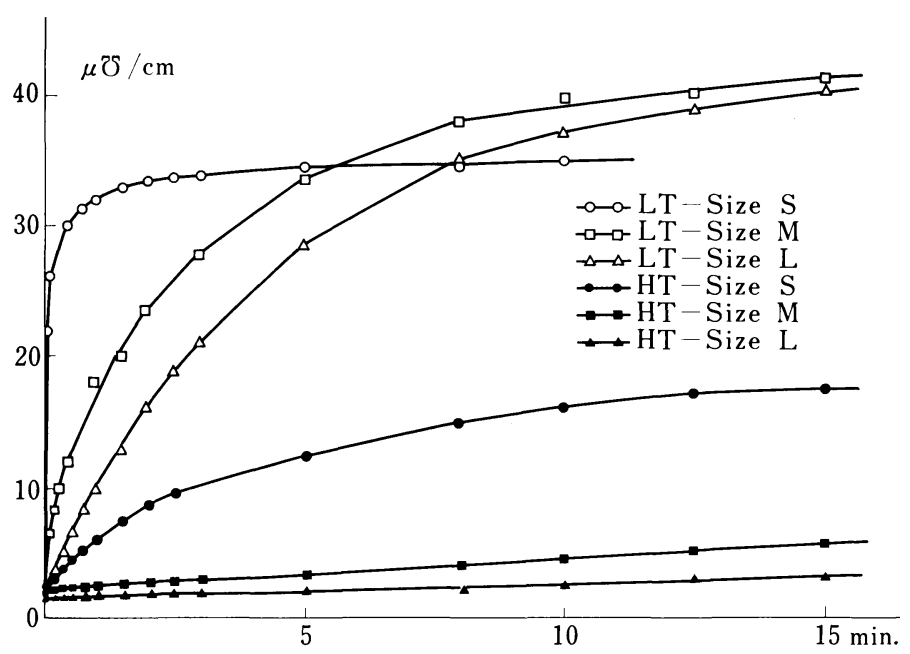

図 7 純水を溶媒とした場合の比電導度の変化

いた（図 20）。

処置後 4 週において, 対照群, LT の 3 種すべてと, HT-size M および size L でも, 既に骨修復はほぼ完了 しており，骨髄腔も認められた（図 21）。

2 週例において骨修復の遅れていた HT-size S でも， ほぼ骨修復は完了しており，骨内に埋入された多くの hydroxyapatite を認めた（図 22)。

また 2 週例および 4 週例において, 異物巨細胞の hydroxyapatite 周囲への出現はごく稀であり, 被膜形成 や急性炎症性細胞浸潤の所見はみられなかった。

\section{考案}

以上述べた実験結果を, hydroxyapatite と組織反応お よび hydroxyapatite の骨誘導能について考案し, hydroxyapatite の臨床応用の可否を検討した。

\section{1. hydroxyapatite と組織反応}

組織に埋入された implant 材に対する生体反応の第 1 段階として，線維性結合織による implant 材の被包を あげた報告は, hydroxyapatite について Denissen ら", 倉科 ${ }^{2)}$, TCP について Bhaskar $ら^{3)}$, Levin $ら^{4-6)}$, 


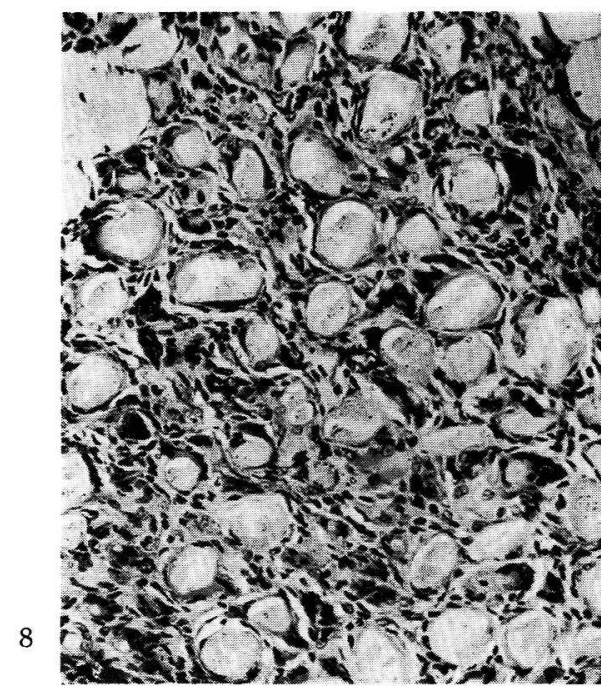

図 8 LT-size S 筋肉内埋入試験 2 週例 (H.E. 染色)。 線維性結合織が hydroxyapatite を被包している。×215

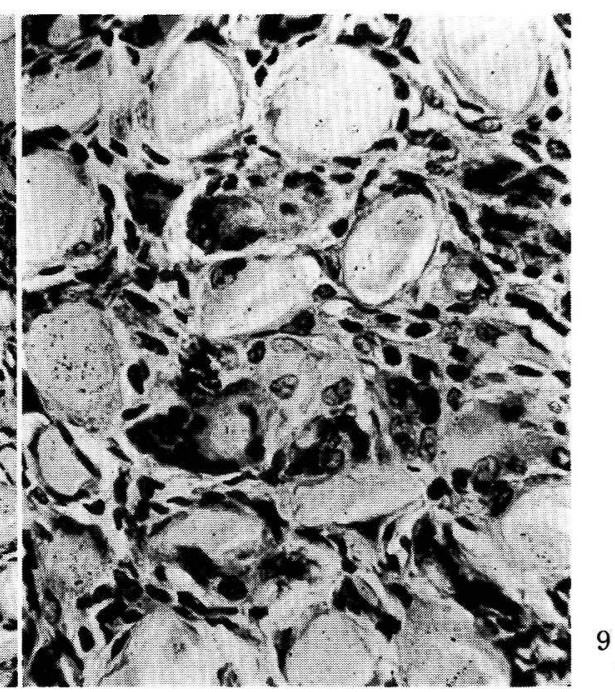

図 9 図 8 の抎大像。 多核の異物巨細胞が hydroxyapatite に密着して存在している。 $\times 215$

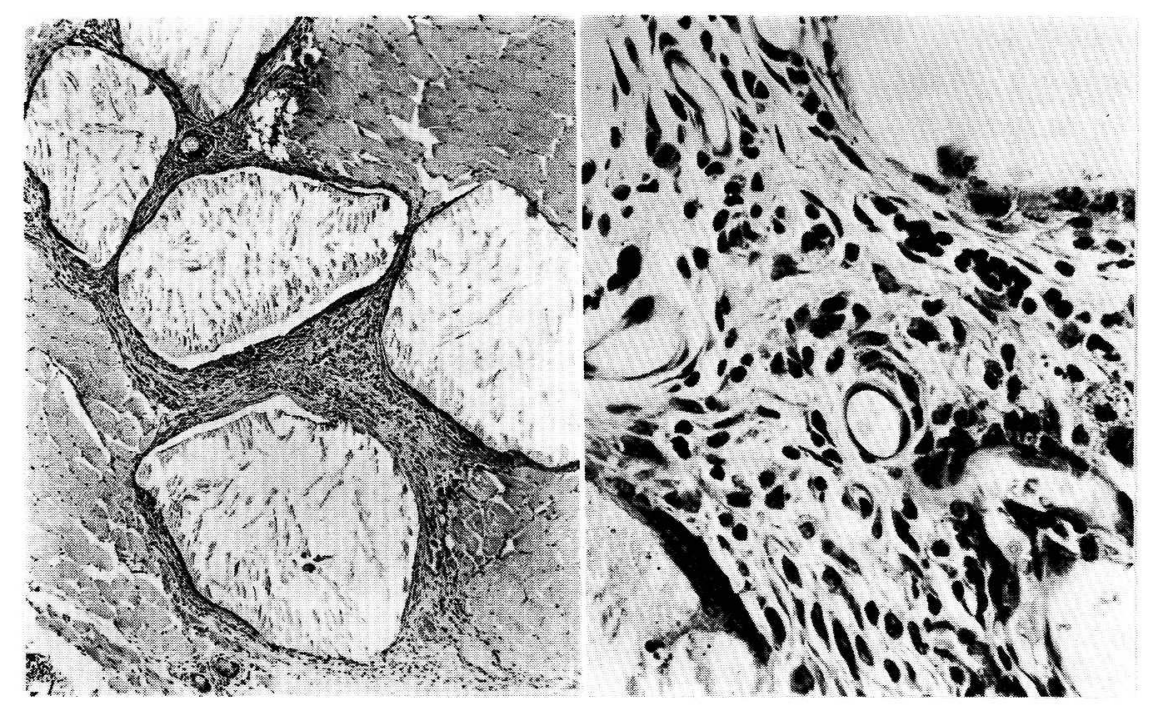

図 10 LT-size L 筋肉内埋入試験 4 週例 (H.E. 染色)。

hydroxyapatite は周囲筋組織か ら隔離されている。周囲筋組織の 障害像はみられない。 $\times 58$

図 11 LT-size M筋肉内埋入試験 4 週例 (H.E. 染色)。軽度の慢性炎症性 細胞浸潤がみられる。 $\times 430$
Nery $5^{7)}$, alumina ceramic について Bhaskar $ら^{8)}$, Pedersen $5^{9)}$ のもがある。これに関して不二崎 ${ }^{10)}$ は, 金属などの化学的活性をもつものに対しては，被包とい う形で膠原線維被膜をつくって化学的刺激を防ぐとし，
青木ら ${ }^{11)}$ も, 組織内埋入材料の刺激性の序列に従って被 膜の厚みが定まるという事実から，線維性被膜は生体の 防御反応であるとして, 被膜形成を化学的刺激の結果と する観点で説明している。これに対し Cameron ら ${ }^{12)}$ は, 


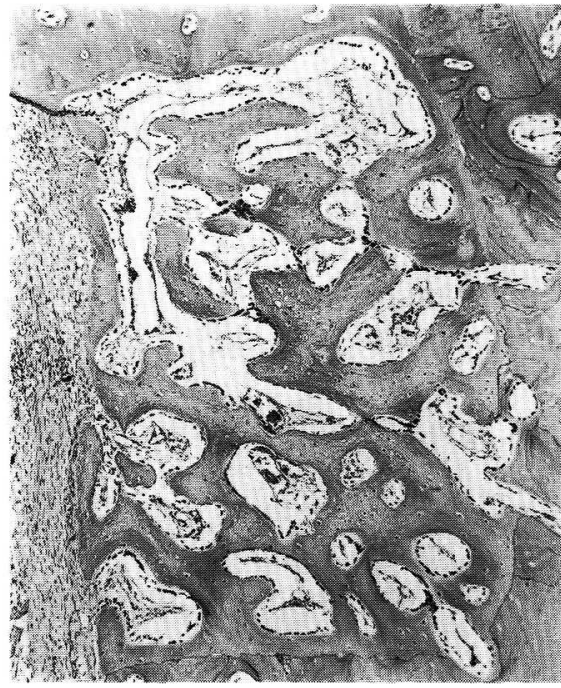

図 12 顎骨内埋入試験対照 2 週例 (H.E. 染色)。

再生骨梁が骨欠損窩洞表層をも塞 ぐように存在する。×58

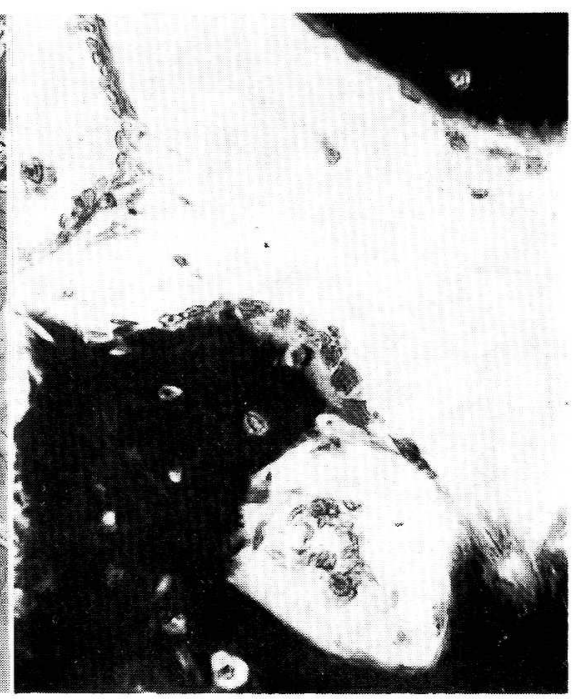

図 13 顎骨内埋入試験対照 2 週例 (Azan 染色)。

再生骨梁に密着して存在する，細 胞質が濃染された骨芽細胞。×460

かと推察している。

本実験でも顎骨内埋人試験の 4 週例では, 対照および ほとんどの実験群において骨修復はほぼ完了していた が， 2 週例では詨照群の方が骨梁の再生はより進行して いた。これは橋本のいうように, hydroxyapatiteが骨火 損部を占有しているための骨再生の遅延をあらわすもの かもしれない。しかし臨床に㧍いては，歯周治療後病的 に吸収されていた歯槽骨久損部の再生添加はほとんどみ られないが，本実験では対照群の実験的な欠損部にも骨 修復がみられ，創傷治癒として骨再生が起こっていたも のと思われる。それ故に, 両者の骨修復状況は本質的に 異なっており, 本実験では, 2 週例において hydroxyapatite の表面に沿って骨梁が再生し，4週例で骨修復 はほぼ完了している所見から, hydroxyapatite が骨芽細 胞や骨組織再生に対して何ら障害を与えていない点を重 要だと考えた。

\section{2. hydroxyapatite $の$ 骨誘導能}

hydroxyapatite $の$ 骨誘導能について, 高橋ら hydroxyapatite 周囲の線維芽細胞が骨芽細胞に分化し つつある像や, hydroxyapatite 周井に骨芽細胞や骨細胞 が固着しこれから新生骨が形成されている事実より，何 らかの学形成因子を刺激していることは明らかであると 述べており, 倉科ら ${ }^{16)}$, 山崎 ${ }^{17)}$, 小木㽚 ${ }^{18)}$ も同様の見解 をとっている。更に青木らは，アパタイト焼結体が難溶 


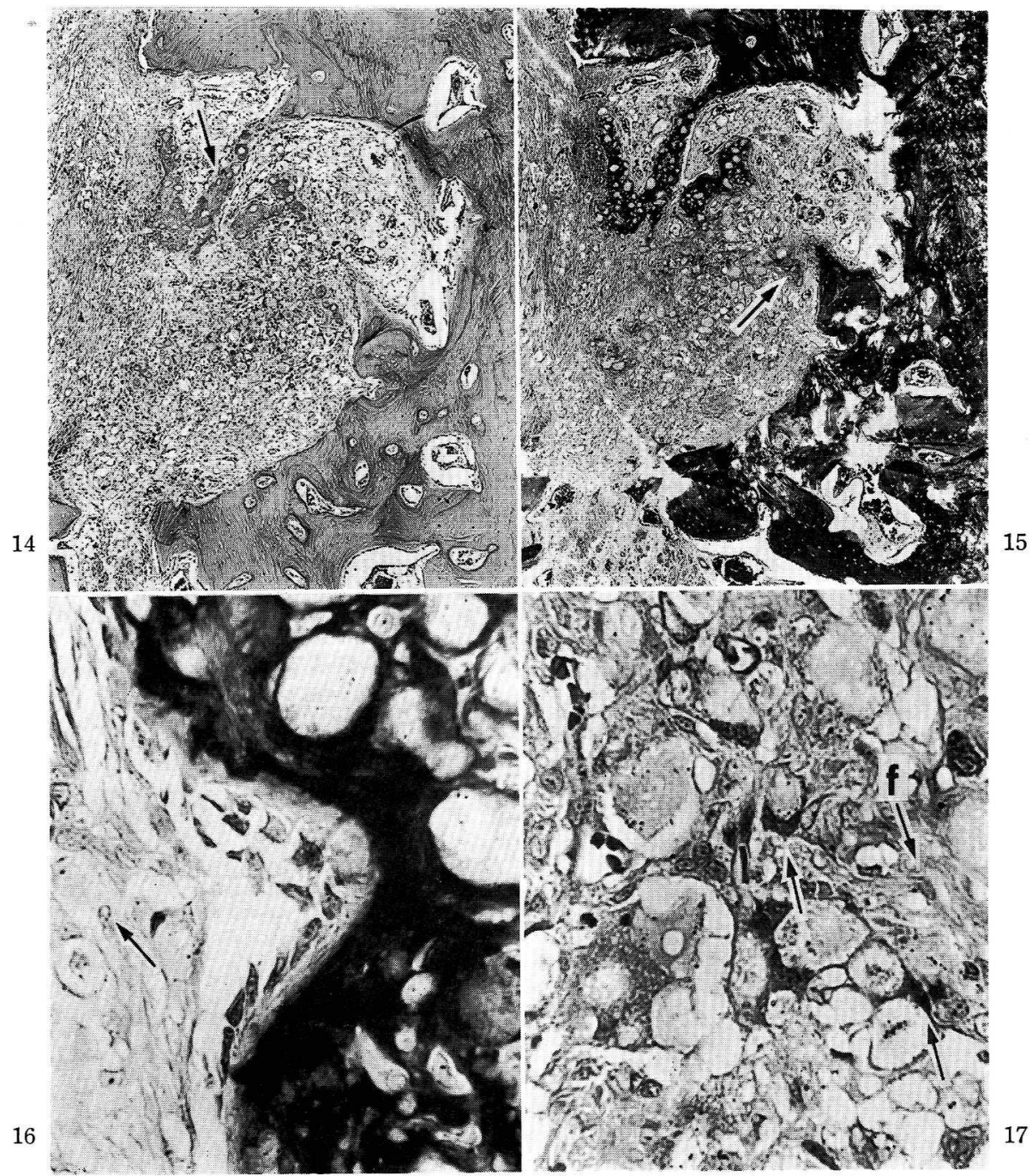

図 14 LT-size S 顎骨内埋入試験 2 週例 (H.E. 染色)。骨梁の再生は遅れて いる。一部に hydroxyapatite (知印) を含む再生骨梁がみられる。 $\times 42$

図 15 図14のAzan 染色。結合織内にやや濃染する類骨様構造物 (知印) がみられる。 $\times 42$

図 16 図 15 の拡大像。hydroxyapatite を含む再生骨梁に密直して存在する 骨芽細胞。線維芽細胞 (知印) との染色性の相違に注意。 $\times 550$

図 17 図 15 の結合織部の拡大像。hydroxyapatite に密直して, 細胞質が濃 染する細胞が存在する (久印)。線維芽細胞 (矩印 f) との染色性の相 違に注意。 $\times 550$

性ではあるが，蒸溜水あるいは弱酸に溶解することか ら，これらが体内に埋入された場合，埋入局所の体液の カルシウムおよびリン酸イオン濃度は周囲に比べ高くな ると同時に, $\mathrm{pH}$ もいくぶノルカリ側に移動する。そ
してこれらの化学的効果が骨組織の生理作用に何らかの 活性を起こすのではないかとしている。

本実験でも，既存の骨組織から伸びた再生骨梁が hydroxyapatite を埋入した所見や, 結合織内の線維芽 


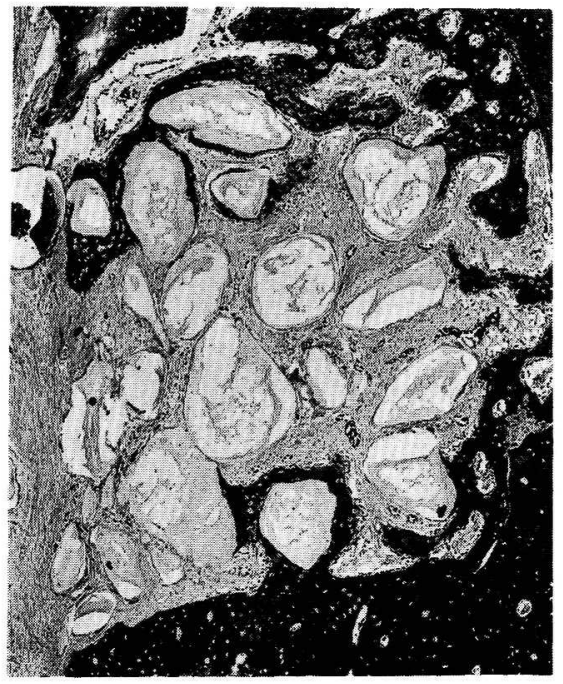

図 18 LT-size M 額骨内埋入試験 2 週 例 (Azan 染色)。 骨梁が hydroxyapatite を包み 込むようにして再生している。 $\times 46$

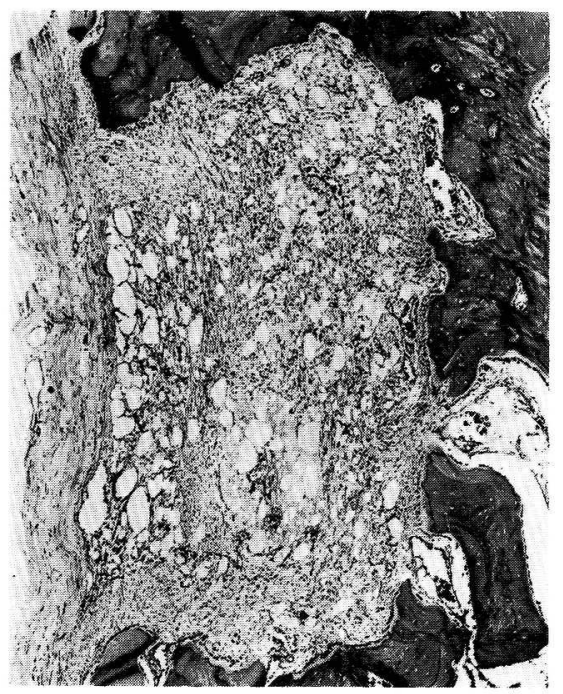

図 19 HT-size S 顎骨内埋入試験 2 週 例 (H.E. 染色)。

再生骨梁はほとんどみられな w。 $\times 43$

細胞中に骨芽細胞と同様の染色性を有する細胞がみら れ，一部には類骨様構造物が存在する所見が得られてお り，本実験に使用した hydroxyapatite む何らかの骨誘 導能を有するものと思われた。

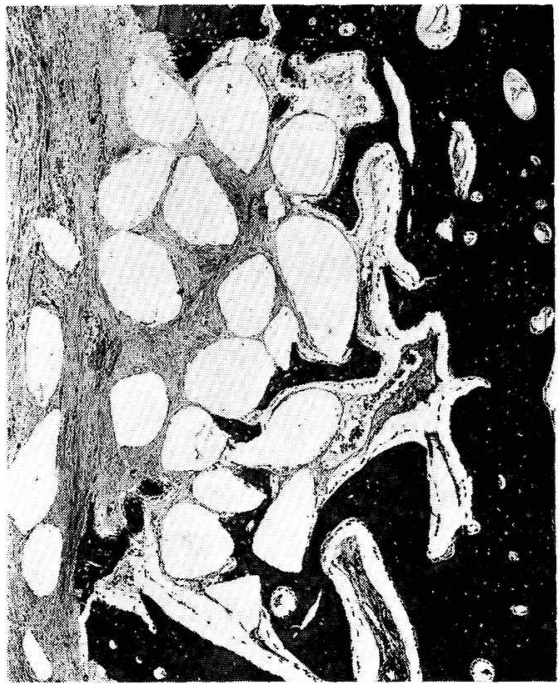

図 20 HT-size M 顎骨内埋入試験 2 週 例 (Azan 染色)。

軽度の骨梁再生がみられる。 $\times 43$

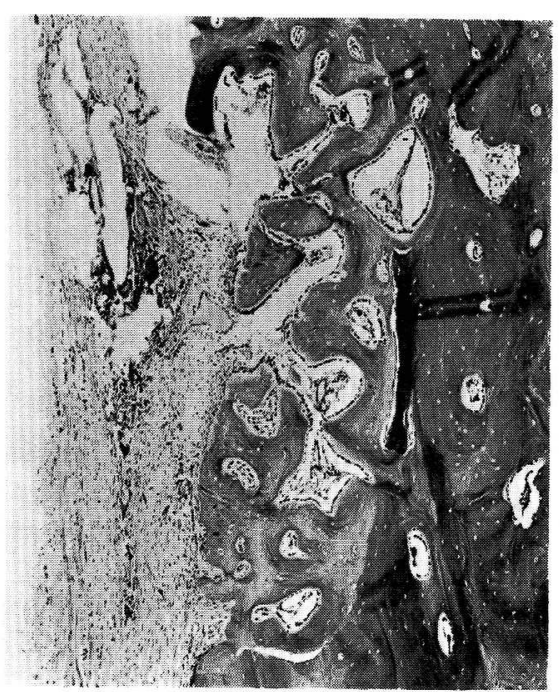

図 21 HT-size M 顎骨内埋入試験 4 週 例 (H.E. 染色)。 骨修復は，骨欠損窝洞の表層を 残すのみとなっている。 $\times 52$

また使用した 6 種類の hydroxyapatite を, 焼成温度 で分ければ LT の方が，粒子の径で分ければ size M お よび size L の方が骨梁の再生は活発であった。

焼成温度による相違に関しては, LT の方が比電 導 試 


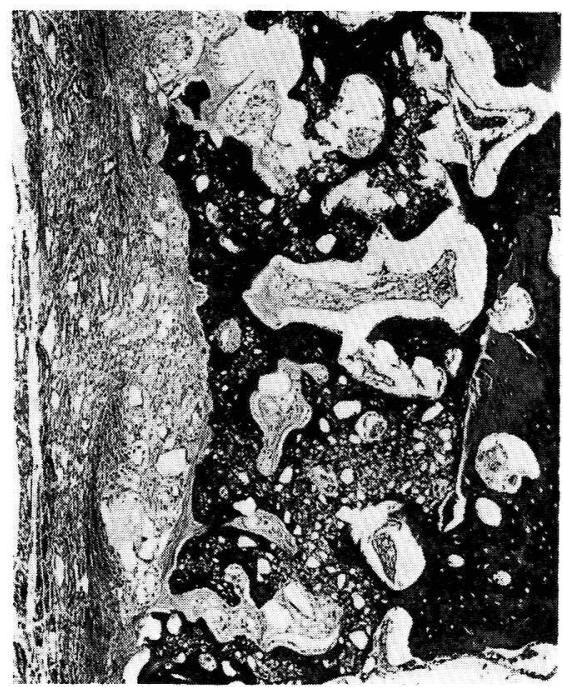

図 22 HT-size S 顎骨内埋入試験 4 週 例 (Azan 染色)。 骨修復はほぼ完了している。 再生骨梁内に白くぬけてみえる のは hydroxyapatite である。 $\times 55$

験で溶解性が高く, 表面微細構造は粗造で大小の起伏に 富み，より広く組織と接触するために骨再生が活発なの ではないかと思われた。

金田 ${ }^{19)}$ は，埋入した hydroxyapatite と骨の間隙が 50 $\mu \mathrm{m}$ 以下では組織分化が遅く, $100 \mu \mathrm{m}$ 以上では組織分化 の進行が速いと述べている。これを参考にして粒子の径 による相違を考案すると, size S は粉末状であり埋入時 に容易に緻密な填塞がなされるのに対し, size M および size L は顆粒状であるため, 同様の填塞圧を加えても hydroxypapatite 間の間隙はより広く維持されるため に, 組織分化の差異が生じたのではないかと考えられ た。

以上の考案を総括すると, 本実験に使用した hydroxyapatite は, 組織に対する化学的刺激性はなく生体への 高い親和性を示し, 何らかの形で骨誘導能を有するもの と考えられた。また，6種の hydroxyapatite のうち, 焼成温度では LT の方に, 粒子の径では size M および size L の方により高い骨修復像を認めた。

現在, 我々は hydroxyapatiteに関しては, LT-size M を用いてイヌの実験的歯周炎における骨修復を，X線規 格撮影を応用して病理組織学的に検索しており, TCPに 関しても hydroxyapatite と同様の基礎実験を行ってい るが，今後は更に両者の臨床応用を検討してゆきたいと
考えている。

\section{結論}

然成温度 $\left(900^{\circ} \mathrm{C}\right.$ および $\left.1,400^{\circ} \mathrm{C}\right)$, 粒子の径 $(100 \mu \mathrm{m}$ 以下, 200〜300 $\mu \mathrm{m}$ および 500〜 1, $000 \mu \mathrm{m})$ が異なる 6 種類の hydroxyapatite を歯周治療に応用す心゙く, その 基礎実験として表面微細構造の観察，比電導度試験， 2 週と 4 週のラット筋肉内埋入試験およびイヌ鿓骨内埋入 試験を行い, hydroxyapatite と組織反応および hydroxyapatite の骨誘導能について病理組織学的に検索 し, 以下に示寸結論を得た。

1. 焼成温度 $900^{\circ} \mathrm{C}$ の hydroxyapatite $の$ 表面微細構 造は, 緩徐に起伏して微細顆粒状を呈し, $1,400^{\circ} \mathrm{C}$ の のは散在する孔の存在を除いてはより滑沢であった。

2. 純水および $0.1 \%$ 希塩酸を溶媒とし， $250 \mathrm{mg}$ の 各 hdroxyapatite を溶質とする比電導度試験では, 焼成 温度 $900^{\circ} \mathrm{C}$ の hydroxyapatite の方がより高い溶解性を 示した。

3. 笳肉内埋入試験では, 2 週および 4 週例共に hydroxyapatite は異物巨細胞を伴う線維性被膜によっ て被包されており, 軽度の慢性炎症性細胞の浸潤もみら れた。

4. 顎骨内埋入試験 2 週例では, 焼成温度 $900^{\circ} \mathrm{C}$ の hydroxyapatite の方が焼成温度 $1,400^{\circ} \mathrm{C}$ のものよりも, やや速やかな骨修復像を呈していたが, 対照群に比べる と実験群はすべて，やや遅れていた。また，再生骨梁や 類骨様構造物のみられない結合織 中に tite に密接して骨芽細胞様細胞が存在していた。

顎骨内埋入試験 4 週例では, 対照群およびほとんどの 実験群で骨修復はほぼ完了していたが, 焼成温度 $1,400^{\circ} \mathrm{C}$, 径 $100 \mu \mathrm{m}$ 以下のものはやや骨修復が遅れて いた。

2 週および 4 週例を通じ異物巨細胞の出現はごく稀で あった。また, hydroxyapatite に対する被膜形成や急性 炎症性細胞浸潤の所見は認められなかった。

5. 骨修復状況は, 焼成温度 $900^{\circ} \mathrm{C}$, 径 $200 \sim 300 \mu \mathrm{m}$ ないし 500〜1,000 $\mu \mathrm{m}$ のものが良好であった。

以上の結果より, hydroxyapatite は非刺激性で, 生体 親和性と骨誘導能を有することが推察された。

\section{文献}

1) Denissen, H.W., de Groot, K., Makkes, P. Ch., 
Van den Hooff, A. and Kloopper, P.J. : Tissue response to dense apatite implants in rats. J. Biomed. Mater. Res., 14 : 713-721, 1980.

2）倉科憲治, 小谷 朗, 田中 寿, 都田芳弘, 尾野 幹也：Ceramics 材料の臨床応用に関する研究.

第一報: Dence calcium hydroxyapatite ceramics に対する骨の反応. 信州医誌, $30: 161-173$, 1982.

3) Bhaskar, S.N., Brady, J.M., Getter, L., Grower M.F. and Driskell, T. : Biodegradable ceramic implants in bone. - Electron and light microscopic analysis -. Oral Surg., $32: 336-346$, 1971.

4) Levin, M.P., Getter, L., Cutright, D.E. and Bhaskar, S.N. : Biodegradable ceramic in periodontal defects. Oral Surg., 38 : 344-351, 1974.

5) Levin, M.P., Getter, L., Adrian, J. and Cutright, D.E. : Healing of periodontal defects with ceramic implants. J. Clin. Periodontol., $1:$ 197-205, 1974.

6) Levin, M.P., Getter, L. and Cutright, D.E. : A comparison of iliac marrow and biodegradable ceramic in periodontal defects. J. Biomed. Mater. Res., 9 : 183-195, 1975.

7) Nery, E.B., Lynch, K.L., Hirthe, W.M. and Mueller, K.H. : Bioceramic implants in surgically produced infrabony defects. J. Periodontol, $46: 328-347,1975$.

8) Bhaskar, S.N., Cutright, D.E., Knapp, M.J., Beasley, J.D., Perez, B. and Driskell, T.D. : Tissue reaction to intrabony ceramic implants. Oral Surg., 31 : 282-289, 1971.

9) Pedersen, K.N., Haanae, H.R. and Lyng, S. : Tissue ingrowth into mandibular intrabony porous ceramic implants. Int. J. Oral Surg., 3 : 158-165, 1974.
10）不二崎正径 : 微細化したアルミナセラミックに対 する組織反応について． 補 綴 誌，26:13-29, 1982.

11）青木秀希, 加藤一男, 小木賏誠, 田端恒雄 : 新し い歯科インプラント材料としてのアパタイト焼結 体. 歯界展望, $49: 567-575,1977$.

12) Cameron, H.U., Pilliar, R.M. and Macnab, I. : The effect of movement on the bonding of porous metal to bone. J. Biomed. Mater. Res., $7: 301-311,1973$.

13) Schatzker, J., Horne, J.G. and Summer-Smith, G. : The effect of movement on the holding power of screws in bone. Clin. Orthop., 111 : 257-262, 1975.

14）橋本公示 : Infrabony pocket $へ$ plaster implant 応用に関する基礎的研究. 一実験的骨欠損に対す る paste 状 plaster の応用一. 日歯周誌, 25 ： 44-65, 1983.

15）高橋 忍, 丹羽滋郎, 澤井一彦, 田賀井秀夫, 尾 野幹也, 福田恭森 : 人工移植骨材としての合成水 酸アパタイト。医学のあゆみ, $116: 156-157$, 1981.

16）倉科憲治, 小谷 朗, 尾野幹也: Ceramics 材料 の臨床応用に関する研究. 第二 報 : Porous calcium hydroxyapatite ceramics に対する骨の反 応. 信州医誌, $30: 174-181,1982$.

17）山崎安晴, 大西正俊, 塩田重利, 小木曾誠, 一条 尚：人工骨としての多孔質アパタイトー1. 脛骨 埋入実験一. 口病誌, $49: 251-278,1982$.

18）小木既誠：アパタイト表面における骨組織形成な らびにその石灰化について。病誌，50:1-22, 1983.

19）金田浩之：Apatite implant の埋入間隙と骨組織 形成との関連性に関する観察. 口病誌，47:5797, 1980. 